\title{
PENGARUH KECUKUPAN MODAL, LIKUIDITAS, DAN NON PERFORMING LOAN TERHADAP PROFITABILITAS PADA LPD DI KOTA DENPASAR
}

\author{
I Gst Ayu Nyoman Krisnia Putri ${ }^{1}$ \\ I Ketut Mustanda ${ }^{2}$
}

\author{
${ }^{1,2}$ Fakultas Ekonomi dan Bisnis Universitas Udayana (Unud), Bali, Indonesia \\ E-mail: krisnia.putri@yahoo.co.id
}

\begin{abstract}
ABSTRAK
Tujuan penelitian ini adalah untuk mengetahui pengaruh Kecukupan Modal, Likuiditas, dan Non Performing Loan terhadap Profitabilitas. Penelitian ini dilakukan pada Lembaga Perkreditan Desa di Kota Denpasar periode 2015 sampai 2017. Jumlah sampel yang digunakan sebanyak 35 LPD. dengan metode sampling jenuh. Metode pengumpulan data yang digunakan adalah metode observasi non participant yaitu melalui observasi dilakukan terhadap dokumen publikasi data laporan keuangan LPD. Jenis data yaitu data Kuantitatif. Sumber data yang digunakan adalah data sekunder.Teknik analisis yang digunakan adalah regresi linear berganda. Penelitian ini membuktikan bahwa Kecukupan Modal dan Likuiditas berpengaruh positif dan signifikan terhadap Profitabilitas hal ini menunjukkan bahwa Kecukupan Modal dan Likuiditas berpengaruh terhadap kenaikan atau peningkatan profitabilitas, sedangkan Non Performing Loan berpengaruh negatif dan signifikan terhadap profitabilitas hal ini menunjukkan bahwa apabila terjadi peningkatan pada Non Performing Loan maka Profitabilitas mengalami penurunan.
\end{abstract}

Kata Kunci : kecukupan modal, likuiditas, NPL, profitabilitas

\begin{abstract}
The purpose of this study was to determine the effect of Capital Adequacy, Liquidity, and Non-Performing Loans on Profitability. This research was conducted at Village Credit Institutions in Denpasar City for the period 2015 to 2017. The number of samples used was 35 LPDs. with saturated sampling method. The data collection method used is the nonparticipant observation method, namely through observations made on the publication documents of LPD financial report data. Type of data is Quantitative data. The data source used is secondary data. The analysis technique used is multiple linear regression. This study proves that Capital Adequacy and Liquidity have a positive and significant effect on Profitability. This shows that Capital Adequacy and Liquidity affect the increase or increase in profitability, while Non Performing Loans have a negative and significant effect on profitability, this indicates that if there is an increase in Non Performing Loans then Profitability has decreased.
\end{abstract}

Keywords: capital adequacy, liquidity, NPL, profitability 


\section{PENDAHULUAN}

Setiap perusahaan dalam menjalankan kegiatan usahanya tidak terlepas dari tujuan utamanya yaitu untuk mendapatkan dan memperoleh keuntungan atau laba yang maksimal mungkin dalam keberlangsungan hidup usahanya. Dengan memperoleh laba yang maksimal seperti yang telah ditargetkan, perusahaan dapat berbuat banyak bagi kesejahteraan pemilik, karyawan, serta meningkatkan mutu produk dan melakukan investasi baru (Kasmir, 2010:196). Di dalam dunia usaha merupakan dunia yang paling ramai dibicarakan di berbagai forum, baik yang bersifat nasional maupun internasional. Ini merupakan salah satu tolak ukur kemajuan suatu negara adalah dari kemajuan ekonominya dan tulang punggung dari kemajuan ekonominya (Kasmir, 2013:2).

Masalah pokok dan paling sering dihadapi oleh setiap perusahaan tidak terlepas dari kebutuhan akan dana atau modal untuk membiayai usahanya. Dana memang dibutuhkan baik untuk perusahaan yang baru berdiri maupun sudah berjalan bertahun-tahun. Seiring dengan pertumbuhan ekonomi yang semakin meningkat muncul berbagai macam perusahaan yang bergerak di dalam bidang keuangan yang memegang peranan penting dalam memenuhi akan kebutuhan dana (Kasmir, 2013:2).

Suatu sistem perekonomian perbankan merupakan salah satu pilar terpenting dalam membangun sistem perekonomian dan keuangan Indonesia. Bank dikenal sebagai lembaga keuangan yang kegiatan utamanya menerima simpanan giro, tabungan dan deposito. Bank dikenal sebagai tempat untuk meminjam uang (kredit) bagi masyarakat yang membutuhkannya dan sebagai 
I Gst Ayu Nyoman Krisnia Putri, Pengaruh Kecukupan Modal......

tempat untuk menukar uang, memindahkan uang atau menerima segala macam bentuk pembayaran, disamping menyalurkan dana atau memberikan pinjaman kredit juga melakukan usaha menghimpun dana dari masyarakat luas dalam bentuk simpanan (Kasmir, 2013:5).

Salah satu lembaga keuangan yang memberikan pinjaman, melakukan penyaluran dana, dan menghimpun dana dalam bentuk tabungan, deposito maupun kredit yaitu Lembaga Perkreditan Desa. Lembaga Perkreditan Desa merupakan salah satu unsur kelembagaan Desa Pakraman yang menjalankan fungsi keuangan Desa Pakraman untuk mengelola potensi keuangan Desa Pakraman di Bali, setiap daerah di Bali memiliki Lembaga Perkreditan Desa masing-masing, lembaga ini sangat berpotensi dan telah terbukti dalam memajukan kesejahteraan masyarakat desa dan memenuhi desa itu sendiri.

Keberadaan Lembaga Perkreditan Desa (LPD) di masyarakat telah banyak mengalami perkembangan. Perkembangan ini dilihat melalui jumlah asset yang dimiliki dan jumlah keuntungan yang diperoleh, ukuran kinerja keuangan di LPD pada umumnya dilihat dari kemampuan suatu LPD dalam menghasilkan laba, semakin tinggi kemampuan menghasilkan laba, diasumsikan semakin kuat LPD untuk dapat bertahan dalam suatu kondisi ekonomi (Ariani, 2015). Kegiatan yang dilakukan LPD khususnya LPD di Kota Denpasar yaitu menghimpun dan menerima dana dari masyarakat desa dalam bentuk berupa tabungan, deposito, dan memeberikan pinjaman kepada masyarakat desa. Di dalam meningkatkan dan mempertahankan usahanya, LPD juga memerlukan kinerja yang handal di dalam keuangan yaitu dalam pengelolaan asset dan liabilities agar laba yang diperoleh 
LPD menjadi semakin meningkat (Hendiartha, 2015). Keberadaan LPD Di Kota Denpasar memberikan manfaat utama bagi perekonomian pedesaan, dengan adanya LPD masyarakat bisa menabung sekaligus meminjam dana dalam bentuk kredit, saat ini Kota Denpasar memiliki LPD yang tersebar di setiap kecamatan, sebagai berikut :

Tabel 1.

Penyebaran LPD di Kota Denpasar Menurut Kecamatan Tahun 2015-2017

\begin{tabular}{ccc}
\hline No. & Kecamatan & Jumlah LPD \\
\hline 1 & Denpasar Utara & 10 \\
2 & Denpasar Timur & 12 \\
3 & Denpasar Selatan & 11 \\
4 & Denpasar Barat & 2 \\
& Jumlah & 35 \\
\hline
\end{tabular}

Sumber: Data diolah, 2018

Berdasarkan Tabel 1 menunjukkan bahwa periode 2015-2017 Jumlah LPD di Kota Denpasar sebanyak 35 LPD dengan 4 kecamatan terdiri dari Denpasar Utara sebanyak 10 LPD, Denpasar Timur sebanyak 12 LPD, Denpasar Selatan sebanyak 11 LPD, Denpasar Barat sebanyak 2 LPD.

Tabel 2.

Laba Bersih, Total Aktiva, dan Return on Assets (ROA) LPD di Kota Denpasar Tahun 2015-2017

\begin{tabular}{llcccl}
\hline No. & Kecamatan & Tahun & Laba Bersih & Total Aktiva & ROA (\%) \\
\hline 1 & Denpasar Utara & 2015 & 13.529 .612 & 287.935 .730 & 4,70 \\
& & 2016 & 14.618 .696 & 326.706 .474 & 4,47 \\
& & 2017 & 15.454 .566 & 385.190 .933 & 4,01 \\
2 & \multirow{2}{*}{ Denpasar Timur } & 2015 & 16.913 .814 & 351.781 .569 & 4,81 \\
& & 2016 & 18.931 .616 & 408.031 .310 & 4,64 \\
3 & 2017 & 19.745 .114 & 477.483 .752 & 4,14 \\
& \multirow{4}{*}{ Denpasar Selatan } & 2015 & 28.412 .901 & 605.202 .955 & 4,69 \\
& & 2016 & 30.013 .539 & 730.086 .852 & 4,11 \\
4 & \multirow{2}{*}{ Denpasar Barat } & 2017 & 31.305 .506 & 871.083 .551 & 3,59 \\
& & 2015 & 6.148 .881 & 138.976 .121 & 4,42 \\
& & 2016 & 6.653 .674 & 160.786 .350 & 4,14 \\
\hline
\end{tabular}

Sumber: Data diolah, 2018

Berdasarkan dari Tabel 2 dapat terlihat di tahun 2015 laba bersih tertinggi dimiliki oleh kecamatan denpasar selatan sebesar Rp 28.412.901. sedangkan laba 
bersih terendah dimiliki oleh denpasar barat sebesar Rp. 6.148.881. Total aktiva tertinggi di tahun 2015 dimiliki oleh denpasar selatan sebesar Rp 605.202.995 sedangkan total aktiva terendah dimiliki oleh denpasar barat sebesar $\mathrm{Rp}$ 138.976.121. terlihat bahwa dari tahun 2015 hingga tahun 2017 kecamatan denpasar memiliki laba bersih dan total aktiva tertinggi sedangkan kecamatan denpasar barat memiliki total laba bersih dan total aktiva terendah.

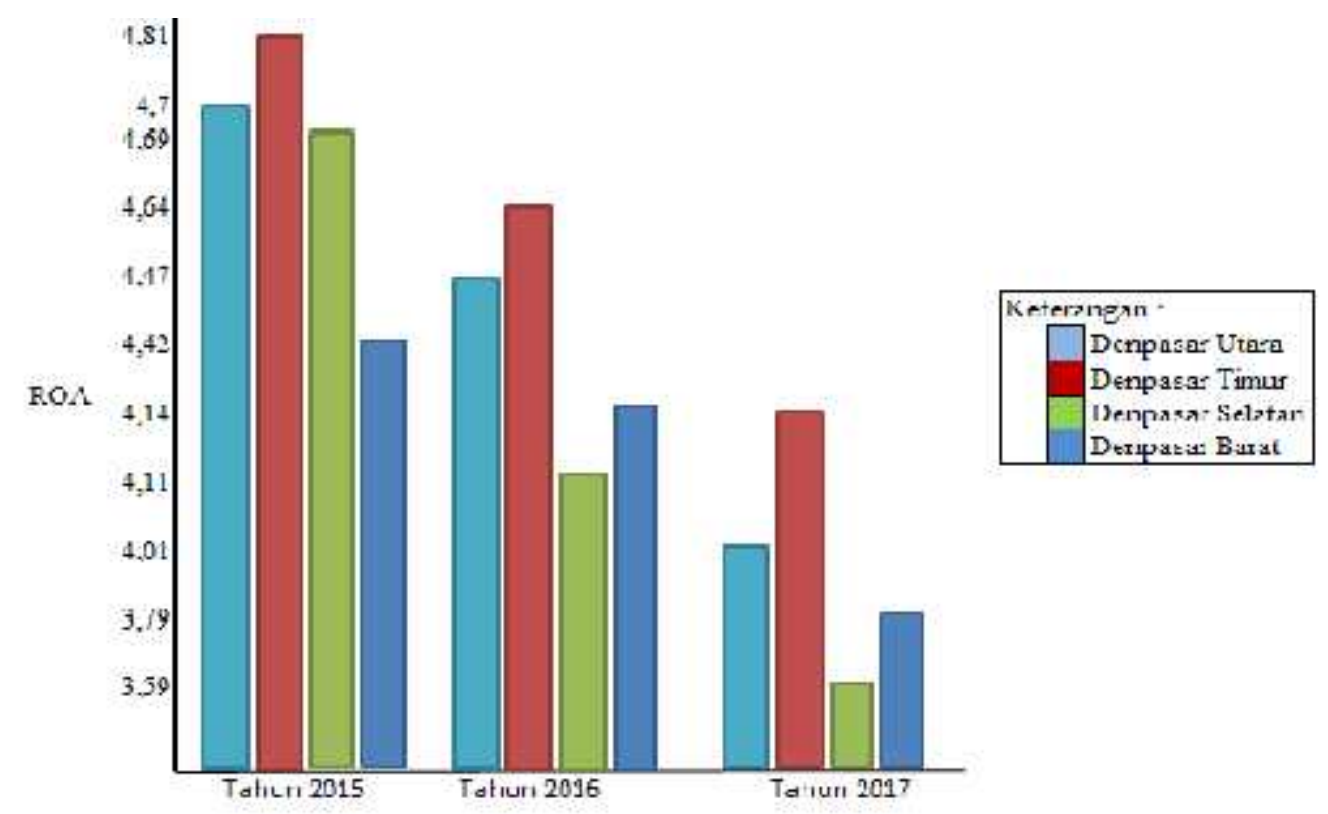

\section{Gambar 1.Grafik Return on Assets (ROA) LPD di Kota Denpasar Tahun 2015-2017 \\ Sumber: Data Diolah, 2018}

Berdasarkan Gambar 1 dapat terlihat bahwa total ROA di Denpasar Utara, Denpasar Timur, Denpasar Selatan dan Denpasar Barat mengalami penurunan dari tahun 2015 - 2017, Total ROA Denpasar Utara di tahun 2015 - 2017 menurun dari 4,70 hingga 4,01, sedangkan Denpasar Timur total ROA di tahun 2015 - 2017 menurun dari 4,81 hingga 4,01, sedangkan Denpasar Selatan total ROA di tahun 2015 - 2017 menurun dari 4,69 hingga 3,59, sedangkan total ROA 
Denpasar Barat di tahun 2015 - 2017 menurun dari 4,42 hingga 3,79. Hal ini menunjukkan bahwa LPD mengalami kesulitan untuk menjaga stabilitas pertumbuhan labanya di setiap tahun karena ROA yang semakin menurun setiap tahunnya. LPD dibentuk dengan harapan menjalankan fungsinya dalam penghimpunan dana, mengelola dana, dan menyalurkan kembali dana yang diperoleh dari masyarakat, Pentingnya LPD dalam mendorong pembangunan ekonomi masyarakat desa tidak terlepas dari kemampuan LPD untuk memperoleh laba yang merupakan indikator kinerja perusahaan, kemampuan kinerja yang handal akan mampu memberikan profitabilitas atau laba yang baik bagi LPD (Asri, 2018).

Salah satu yang dapat digunakan dalam mengukur kinerja suatu Lembaga Perkreditan Desa adalah melalui laporan keuangan yaitu dengan melihat profitabilitas tersebut. Dalam melakukan kegiatan operasionalnya Lembaga Perkreditan Desa memiliki tujuan utama yaitu mencapai tingkat profitabilitas yang maksimal (Putri, 2013). Penilaian kinerja keuangan atau profitabilitas biasanya dapat dilihat dari laporan keuangannya per-bulan, per-tiga bulan, maupun per-tahun (Feranika,2016). LPD perlu menjaga profitabilitas yang tinggi agar kinerjanya bagus.

Profitabilitas mencerminkan kemampuan LPD untuk memperoleh atau menghasilkan laba secara efektif, efisien dan mengetahui berapa laba yang diperoleh dalam suatu periode tertentu. Profitabilitas menunjukkan pendapatan yang mampu dihasilkan oleh perusahaan dalam satu atau setiap periode. Tingginya profitabilitas suatu LPD dapat menunjukkan bahwa sebagian besar 
I Gst Ayu Nyoman Krisnia Putri, Pengaruh Kecukupan Modal......

kinerja LPD tersebut dapat dikatakan baik, karena diasumsikan bahwa LPD telah beroperasi secara efektif dan efisien dan memungkinkan LPD untuk memperluas usahanya (Putri, 2013). Profitabilitas adalah kemampuan bank untuk menghasilkan pendapatan yang melebihi biaya, sehubungan dengan basis modal bank. Sektor perbankan yang sehat dan menguntungkan lebih mampu menahan guncangan negatif dan berkontribusi pada stabilitas sistem keuangan.

Menurut Kasmir (2010:196) rasio profitabilitas merupakan rasio untuk menilai kemampuan dalam mencari keuntungan. Rasio ini juga memberikan ukuran tingkat efektifitas manajemen suatu perusahaan. Rasio profitabilitas ditunjukkan oleh laba yang dihasilkan dari penjualan dan pendapatan investasi. Penggunaan rasio profitabilitas dapat dilakukan dengan menggunakan perbandingan antara berbagai komponen yang ada di laporan keuangan, terutama laporan keuangan neraca dan laporan laba rugi. Pengukuran dapat dilakukan untuk bebrapa periode operasi. Tujuannya adalah untuk melihat perkembangan perusahaan dalam rentang waktu tertentu, baik penurunan atau kenaikan, sekaligus mencari penyebab perubahan tersebut.

Return On Assets (ROA) digunakan untuk mengukur profitabilitas dengan mengukur asset yang dananya sebagian besar dari dana simpanan masyarakat. Semakin besar ROA, semakin besar pula tingkat keuntungan yang dicapai, dan semakin baik posisi perusahaan tersebut dari segi penggunaan asset, oleh karena itu, dalam penelitian ini ROA digunakan sebagai ukuran kinerja perusahaan (Herdiartha, 2015). 
Tingkat kecukupan modal juga merupakan hal yang sangat penting untuk diperhatikan karena tingkat kecukupan modal mencerminkan kemampuan bank dalam menanggung risiko kerugian yang mungkin timbul. Capital Adequacy Ratio (CAR) yang merupakan indikator permodalan dijadikan variable yang mempengaruhi ROA didasarkan hubungannya dengan tingkat risiko perusahaan itu sendiri. Kecukupan modal berkaitan dengan penyediaan modal sendiri yang diperlukan untuk menutup risiko kerugian yang mungkin timbul dari pergerakan aktiva bank yang pada dasarnya sebagian besar dana berasal dari pihak ketiga atau masyarakat (Herdiartha, 2015). Menurut peraturan Gubernur Bali No. 44 tahun 2017 LPD harus memenuhi kecukupan modal minimum 12\%. Semakin tinggi CAR maka semakin baik kemampuan perusahaan meningkatkan kepercayaan masyarakat kepada perusahaan, dan pada akhirnya dapat meningkatkan pendapatan suatu perusahaan tersebut. Jadi menurut penelitian Suardita (2015), Hantono (2017), Abdilah et al. (2016) menyatakan bahwa CAR berpengaruh positif dan signifikan terhadap profitabilitas, namun temuan berbeda dilakukan oleh Ismaulina dan Zulfadhli (2016) bahwa CAR berpengaruh negatif dan tidak signifikan terhadap profitabilitas, penelitian lain yang dilakukan oleh Puspitasari et al. (2015):Chou dan Buchdadi (2016) menyatakan bahwa CAR berpengaruh positif namun tidak signifikan terhadap profitabilitas, dan penelitian yang dilakukan oleh Prasanjaya (2013) menyatakan bahwa CAR tidak berpengaruh signifikan terhadap profitabilitas.

Menurut Kasmir (2010:221) Likuiditas merupakan rasio yang digunakan untuk megukur kemampuan bank dalam memnuhi kewajiban jangka pendeknya 
I Gst Ayu Nyoman Krisnia Putri, Pengaruh Kecukupan Modal......

pada saat ditagih. Bank dapat membayar kembali pencairan dana para deposannya pada saat ditagih serta dapat mencukupi permintaan kredit yang telah diajukan, makin besar rasio ini makin likuid. Loan to Deposit Ratio (LDR) merupakan rasio yang digunakan untuk mengukur komposisi jumlah kredit yang diberikan dibandingkan dengan jumlah dana masyarakat dan modal sendiri yang digunakan. Berdasarkan Peraturan Bank Indonesia No.18/14/PBI/2016 pasal 11 batas bawah LDR target sebesar $78 \%$ sedangkan batas atas LDR target sebesar $92 \%$. Temuan yang dilakukan oleh Alshatti (2015), Makkar dan Hardeep (2018) menyatakan bahwa likuiditas berpengaruh positif terhadap profitabilitas, tetapi temuan lain yang dilakukan oleh Ismaulina dan Zulfadhli (2016):Pradhan dan Parajuli (2017):Pinasti dan Mustikawati (2018):Avrita dkk,.(2016) menyatakan bahwa LDR berpengaruh negatif dan tidak signifikan terhadap Profitabilitas (ROA), temuan berbeda dilakukan oleh Acaravci (2013), Arif dan Anees (2012) menyatakan bahwa likuiditas berpengaruh negatif dan signifikan terhadap profitabilitas.

Non Performing Loan (NPL) memiliki erat kaitannya dengan kredit bermasalah, di dalam perbankan kredit merupakan aktifitas penghimpunan dana. Kredit ini merupakan dana pihak ketiga yang di himpun atau ditarik oleh bank yang berasal dari nasabah, kredit ini akibat gagal melakukan pelunasan karena adnya faktor eksternal. Dana yang berasal dari nasabah atau masyarakat berbentuk simpanan, deposito, giro dan dana pihak ketiga lainnya (Feranika, 2016). Jika semakin rendah NPL maka semakin tinggi profitabilitas dan akan meningkatkan profitabilitas. Berdasarkan Peraturan Bank Indonesia No. 
18/14/PBI/2016 pasal 11 batas minimul NPL yaitu $\leq 5 \%$. Penelitian yang diteliti oleh Hartono (2017) menyatakan bahwa NPL berpengaruh negatif dan signifikan terhadap profitabilitas (ROA), penelitian serupa juga diteliti oleh Puspitasari et al. (2015):Kristianti dan Yovin (2016) menyatakan bahwa Non Performing Loan (NPL) berpengaruh negatif terhadap profitabilitas, sedangkan penelitian yang dilakukan oleh Cai dan Huang (2014) menyatakan bahwa NPL memiliki pengaruh positif dengan profitabilitas bank.

Permodalan merupakan hal yang pokok bagi sebuah LPD. Modal digunakan sebagai kegiatan operasional oleh LPD dan digunakan sebagai penyangga kerugian yang mungkin timbul dari LPD tersebut. Capital Adequacy Ratio (CAR) digunakan sebagai rasio untuk mengukur kecukupan modal, CAR mencerminkan modal perusahaan dalam menghasilkan laba. Primadewi (2015) yang menyatakan CAR merupakan tolak ukur kemampuan bank untuk menutupi penurunan aktivanya. Kecukupan modal berkaitan dengan penyediaan modal sendiri yang diperlukan untuk menutup risiko kerugian yang mungkin timbul dari pergerakan aktiva bank yang pada dasarnya sebagian besar dana berasal dari dana pihak ketiga atau masyarakat (Hendiartha, 2015). LPD yang memiliki modal yang cukup besar dapat memperoleh keuntungan yang besar pula, apabila semakin tinggi CAR maka semakin besar modal yang dimiliki oleh LPD. Jika semakin tinggi nilai CAR maka suatu LPD tersebut mampu dalam membiayai operasi LPD dan dalam keadaan tersebut dapat memberikan kontribusi terhadap profitabilitas, dan semakin baik kemampuan meningkatkan kepercayaan masyarakat kepada LPD, dan pada akhirnya dapat meningkatkan suatu pendapatan tersebut. 
Penelitian yang dilakukan Putri (2017) pada lembaga perkreditan desa di kota denpasar periode 2013 - 2015 mendapatkan hasil CAR berpengaruh positif dan signifikan terhadap profitabilitas. Hasil yang sama juga diperoleh pada penelitian Primadewi dan Suputra (2015) pada bank pembangunan daerah bali periode 2005 - 2012 mendapatkan hasil CAR berpengaruh positif dan signifikan terhadap profitabilitas dan hasil penelitian yang dilakukan oleh Suardita dan Putri (2015) pada bank yang terdaftar di bursa efek Indonesia periode 2011 - 2013 menyatakan bahwa CAR berpengaruh positif dan signifikan terhadap profitabilitas.

$\mathrm{H}_{1}$ : Kecukupan Modal berpengaruh positif dan signifikan terhadap Profitabilitas.

Likuiditas menunjukkan kemampuan bank untuk membayar kewajiban financial jangka pendek tepat pada waktunya (Sartono, 2001:116). Jika risiko likuiditas tidak ditangani dengan baik, risiko tersebut bisa mengakibatkan kebangkrutan perusahaan (Hanafi, 2012:239). Kasmir (2004:272) menyatakan Loan to Deposit Ratio (LDR) merupakan rasio untuk mengukur komposisi jumlah kredit yang diberikan dibandingkan dengan jumlah dana masyarakat dan modal sendiri yang digunakan. Jadi semakin besar jumlah dana yang disalurkan kepada nasabah dalam bentuk kredit maka jumlah dana yang menganggur berkurang dan penghasilan bunga yang diperoleh akan meningkat (Herdiartha, 2015). Namun semakin tinggi rasio ini, semakin rendahnya kemampuan likuiditas LPD yang bersangkutan sehingga kemungkinan suatu LPD dalam kondisi bermasalah semakin besar dan dapat mengurangkan total asetnya. Sebaliknya LDR yang semakin rendah menunjukkan kurangnya efektifitas LPD dalam menyalurkan 
dana dalam bentuk kredit sehingga LPD dapat kehilangan kesempatan untuk dapat memperoleh laba. Tinngi rendahnya LDR pada suatu LPD dapat menunjukkan seberapa besar penyaluran yang diberikan dan dapat mempengaruhi profitabilitasnya.

Alshatti (2015) yang menggunakan bank komersial di yordani periode 2005 - 2015 mendapatkan hasil bahwa likuiditas berpengaruh positif terhadap profitabilitas, hasil serupa yang dilakukan oleh Putri (2017) pada LPD di kota denpasar periode 2013 - 2015 yang menyatakan bahwa LDR berpengaruh positif dan signifikan terhadap profitabilitas, dan penelitian yang dilakukan oleh Ariani (2015) pada LPD di kabupaten badung periode 2011 - 2013 yang menyatakan bahwa Loan to Deposit Ratio berpengaruh positif signifikan terhadap profitabilitas.

$\mathrm{H}_{2}$ : Likuiditas berpengaruh positif dan signifikan terhadap Profitabilitas.

Risiko kredit adalah risiko akibat kegagalan nasabah atau pihak lain dalam memenuhi kewajiban kepada bank sesuai perjanjian yang disepakati. Non Performing Loan adalah pinjaman yang mengalami kesulitas pelunasan atau sering disebut sebagai kredit macet pada bank (Riyadi, 2006:161). NPL berpengaruh terhadap penyaluran kredit perbankan dimana terdapat kredit yang memiliki kualitas kredit buruk yang sering disebut dengan kredit bermasalah (Putri, 2017). Jika terdapat masalah kredit bermasalah di suatu bank secara tidak langsung maka akan dapat merugikan masyarakat sebagai pemilik dana (Mahmoeddin, 2001:1). Kredit bermasalah akan berakibat pada kerugian LPD karena tidak diterimanya kembali dana yang telah disalurkan dan pendapatan 
I Gst Ayu Nyoman Krisnia Putri, Pengaruh Kecukupan Modal......

bunganya, maka LPD akan kehilangan kesempatan untuk mendapatkan bunganya yang berakibat pada penurunan pendapatan secara total (Ismail, 2014:222). Pemberian suatu fasilitas kredit mengandung suatu risiko kemacetan, akibatnya kredit tidak dapat ditagih sehingga menimbulkan kerugian yang harus ditanggung oleh LPD. Menurut (Putri, 2015) menyatakan bahwa semakin tinggi kredit bermasalah dalam pengelolaan kredit LPD maka akan menurunkan tingkat profitabilitas LPD, namun sebaliknya jika semakin rendah kredit bermasalah maka akan meningkatkan profitabilitas.

Penelitian yang dilakukan oleh Putri (2015) pada bank umum swasta nasional devisa yang terdaftar di BEI periode 2008 - 2013 yang menyatakan bahwa NPL berpengaruh negatif dan signifikan terhadap profitabilitas, temuan serupan yang dilakukan oleh Ariani (2015) pada LPD di kabupaten badung periode 2011 - 2-13 yang menyatakan bahwa NPL berpengaruh negatif dan signifikan terhadap profitabilitas, dan penelitian yang dilakukan oleh Putri (2017)pada LPD di kota denpasar periode 2013 - 2015 bahwa NPL berpengaruh negatif dan signifikan terhadap profitabilitas. Menurut Kristianti dan Yovin (2016) NPL berpengaruh negatif terhadap profitabilitas pada bank negara dan swasta yang go public di Indonesia periode 2004 - 2013.

$\mathrm{H}_{3}$ : Non Performing Loan berpengaruh negatif dan signifikan terhadap Profitabilitas

\section{METODE PENELITIAN}


Penelitian ini dilakukan di Lembaga Perkreditan Desa yang berada di Kota Denpasar sebanyak 35 LPD. Dengan menggunakan data yang diperoleh dari laporan keuangan tahunan LPD.

Return On Asset (ROA) adalah perbandingan laba tahun berjalan dengan total aktiva pada Lembaga Perkreditan Desa (LPD) di Kota Denpasar sebanyak 35 LPD selama periode 2015 - 2017. Satuan ukurnya adalah persentase, dapat dirumuskan sebagai berikut (Peraturan daerah, No. 3 Tahun 2017):

$$
\mathrm{ROA}=\frac{L \quad n u}{T} X 100 \%
$$

Capital Adequacy Ratio (CAR) adalah mengukur perbandingan antara jumlah modal yaitu modal inti (modal disetor, cadangan umum, laba/rugi tahun berjalan) ditambah dengan modal pelengkap (CPRR/cadangan pinjaman raguragu, akumulasi penyusutan aktiva tetap) dengan Aktiva Tertimbang Menurut Risiko (ATMR) pada Lembaga Perkreditan Desa (LPD) di Kota Denpasar sebanyak 35 LPD selama periode 2015 - 2017. Satuan ukurnya adalah persentase, dapat dirumuskan sebagai berikut (Peraturan daerah No. 3 tahun 2017):

$$
\mathrm{CAR}=\frac{M}{A !} X 100 \%
$$

Loan to Deposit Ratio (LDR) merupakan rasio yang digunakan untuk mengukur jumlah kredit yang diberikan dibandingkan dengan total dana pihak ketiga atau DPK (tabungan, deposito, giro) dan modal inti (modal disetor, cadangan umum, laba/rugi tahun berjalan) yang digunakan pada Lembaga Perkreditan Desa (LPD) di Kota Denpasar sebanyak 35 LPD selama periode 2015 
- 2017. Satuan ukurnya adalah persentase, dapat dirumuskan sebagai berikut (Peraturan Daerah No. 3 tahun 2017):

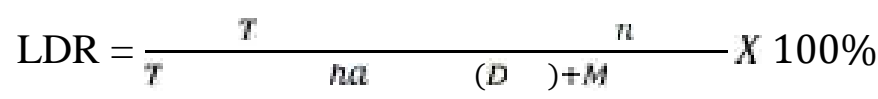

NPL ini adalah perbandingan total kredit bermasalah (dikategorikan sebagai kredit kurang lancar, kredit diragukan, dan kredit macet) dengan total kredit pada Lembaga Perkreditan Desa (LPD) di Kota Denpasar sebanyak 35 LPD selama periode 2015 - 2017. Satuan ukurnya adalah persentase, dapat dirumuskan sebagai berikut (Peraturan Daerah No.3 tahun 2017):

$$
\mathrm{NPL}=\frac{T \ell}{T t_{i}} X 100 \%
$$

Populasi penelitian ini adalah LPD yang berada di Kota Denpasar periode 2015 - 2017. Jumlah populasi LPD di Kota Denpasar adalah sebanyak 35 LPD. Metode penentuan sampel yang digunakan dalam penelitian ini adalah Sampling Jenuh. Sampel dalam penelitian ini adalah LPD yang berada di Kota Denpasar sebanyak 35 LPD periode 2015 - 2017.

Teknik analisis Regresi Linear Berganda digunakan karena dalam penelitian ini variabel terikat dipengaruhi oleh lebih dari satu variabel bebas yang dimana Kecukupan Modal, Likuiditas, Non Performing Loan sebagai variabel bebas dan Profitabilitas sebagai variabel terikat. Bentuk persamaan regresi linier berganda secara sistematis sebagai berikut (Utama, 2016:77) :

$$
\hat{Y}=\alpha+\beta_{1} X_{1}+\beta_{2} X_{2}+\beta_{3} X_{3}+\text { ei }
$$

Keterangan :

$$
\begin{aligned}
& \hat{Y}=\text { Profitabilitas (ROA) } \\
& \alpha=\text { Konstanta } \\
& \beta_{1}, \beta_{2}, \beta_{3}=\text { Koefisien Regresi }\left(X_{1}, X_{2}, X_{3}\right)
\end{aligned}
$$




$$
\begin{aligned}
& \mathrm{X}_{1}=\text { Kecukupan Modal } \\
& \mathrm{X}_{2}=\text { Likuiditas } \\
& \mathrm{X}_{3}=\text { Non Performing Loan } \\
& \text { ei }=\text { Kesalahan Residu }
\end{aligned}
$$

\section{HASIL DAN PEMBAHASAN}

Analisis deskriptif dilakukan untuk memberikan gambaran atau deskripsi suatu data yang dilihat dari nilai rata-rata (mean), standar deviasi, nilai minimum dan nilai maximum mengenai variabel yang diteliti dimana terdiri dari Profitabilitas (Y), Kecukupan Modal $\left(\mathrm{X}_{1}\right)$, Likuiditas $\left(\mathrm{X}_{2}\right)$, dan Non Performing Loan $\left(\mathrm{X}_{3}\right)$, yang terlihat pada tabel 2 . 
Tabel 2.

Hasil Analisis Deskriptif Statistik

\begin{tabular}{|c|c|c|c|c|c|c|}
\hline & & $\mathbf{N}$ & Minimum & Maximum & Mean & $\begin{array}{c}\text { Std. } \\
\text { Deviation }\end{array}$ \\
\hline $\mathrm{Y}$ & & 105 & 1.017 & 8.864 & 4.21427 & 1.485767 \\
\hline $\mathrm{X} 1$ & & 105 & 4.347 & 64.766 & 28.32187 & 10.183072 \\
\hline $\mathrm{X} 2$ & & 105 & 46.330 & 102.619 & 74.34041 & 12.430977 \\
\hline $\mathrm{X} 3$ & & 105 & .003 & 31.157 & 9.88125 & 7.404593 \\
\hline $\begin{array}{l}\text { Valid } \\
\text { (Listwise) }\end{array}$ & $\mathrm{N}$ & 105 & & & & \\
\hline
\end{tabular}

Berdasarkan Tabel 2 dapat diketahui gambaran dari masing-masing variabel adalah jumlah data yang digunakan sebanyak 35 dalam periode 3 tahun (2015 2017) dengan nilai rata-rata (mean) dari ROA Lembaga Perkreditan Desa sebesar 4,21427 persen. Standar deviasi ROA 1,485767. Nilai ROA terendah yang dimiliki adalah 1,017 persen pada tahun 2015 pada LPD Pakraman Serangan dan nilai tertinggi adalah 8,864 persen pada tahun 2015 pada LPD Pakraman Penatih Puri.

Jumlah data yang digunakan sebanyak 35 dalam periode 3 tahun (2015 2017) dengan nilai rata - rata (mean) dari CAR Lembaga Perkreditan Desa sebesar 28,32187 persen. Standar deviasi CAR 10,183072. Nilai CAR terendah yang dimiliki adalah 4,347 persen pada tahun 2015 pada LPD Pakraman Serangan dan nilai tertinggi adalah 64,766 persen pada tahun 2017 pada LPD Pakraman Penatih Puri.

Jumlah data yang digunakan sebanyak 35 dalam periode 3 tahun (2015 2017) dengan nilai rata - rata (mean) dari LDR Lembaga Perkreditan Desa sebesar 74,34041 Persen. Standar deviasi LDR 12,430977 Nilai LDR terendah yang dimiliki adalah 46,330 Persen pada tahun 2015 pada LPD Pakraman Lap- 
Lap dan nilai tertinggi adalah 102,619 persen pada tahun 2015 pada LPD Pakraman Cengkilung.

Jumlah data yang digunakan sebanyak 35 dalm periode 3 tahun (2015-2017) dengan nilai rata - rata (mean) dari NPL Lembaga Perkreditan Desa sebesar 9,88125 persen. Standar deviasi NPL 7,404592. Nilai NPL terendah yang dimiliki adalah 0,003 persen pada tahun 2016 pada LPD Pakraman Denpasar dan nilai tertinggi adalah 31,157 persen pada tahun 2017 Pada LPD Pakraman YangBatu.

Hasil analisis regresi linier berganda penelitian ini dapat ditunjukkan pada Tabel 3.

Tabel 3.

Hasil Analisis Regresi Linier Berganda

\begin{tabular}{|c|c|c|c|c|c|c|c|c|}
\hline \multirow[b]{3}{*}{ Model } & & \multirow{2}{*}{\multicolumn{2}{|c|}{$\begin{array}{l}\text { Unstandardized } \\
\text { Coefficients }\end{array}$}} & \multirow{3}{*}{$\begin{array}{c}\text { Standardized } \\
\text { Coefficients } \\
\text { Beta }\end{array}$} & \multirow[b]{3}{*}{$\mathbf{T}$} & \multirow[b]{3}{*}{ Sig. } & \multicolumn{2}{|c|}{ Collinearity Statistics } \\
\hline & & & & & & & & \\
\hline & & B & $\begin{array}{l}\text { Std. } \\
\text { Error }\end{array}$ & & & & Tolerance & VIF \\
\hline \multirow[t]{4}{*}{1} & (Constant) & $-1,824$ & .656 & & -2.781 & .006 & & \\
\hline & CAR & .131 & .008 & .897 & 15.784 & .000 & .845 & 1.183 \\
\hline & LDR & .038 & .007 & .322 & 5.632 & .000 & .835 & 1.197 \\
\hline & NPL & -.054 & .011 & -.267 & -5.029 & .000 & .969 & 1.032 \\
\hline
\end{tabular}

Berdasarkan Tabel 3, maka diperoleh persamaan hasil regresi llinier berganda sebagai berikut :

$$
\hat{Y}=0,897 X_{1}+0,322 X_{2}-0,267 X_{3}+\text { ei }
$$

Keterangan :

$$
\begin{aligned}
& \mathrm{Y}=\text { Profitabilitas } \\
& \beta_{1}, \beta_{2}, \beta_{3}=\text { Koefisien Regresi }\left(\mathrm{X}_{1}, \mathrm{X}_{2}, \mathrm{X}_{3}\right) \\
& \mathrm{X}_{1} \quad=\text { Kecukupan Modal } \\
& \mathrm{X}_{2} \quad=\text { Likuiditas } \\
& \mathrm{X}_{3} \quad=\text { Non Performing Loan } \\
& \text { ei } \quad=\text { Error }
\end{aligned}
$$

Arti persamaan regresi di atas dapat dijelaskan sebagai berikut : 
I Gst Ayu Nyoman Krisnia Putri, Pengaruh Kecukupan Modal......

$\beta_{1}=0,897$ artinya jika Kecukupan Modal naik sebesar satu persen, maka Profitabilitas (ROA) akan meningkat sebesar 89,7 persen dengan asumsi variabel lainnya konstan atau sama dengan nol.

$\beta_{2}=0,322$ artinya jika Likuiditas naik sebesar satu persen, maka Profitabilitas (ROA) akan meningkat sebesar 32,2 persen dengan asumsi variabel lainnya konstan atau sama dengan nol.

$\beta_{3}=-0,267$ artinya jika Non Performing Loan naik sebesar satu persen, maka Profitabilitas (ROA) akan menurun sebesar 26,7 persen dengan asumsi variabel lainnya konstan atau sama dengan nol.

Uji kelayakan model $\mathrm{F}$ bertujuan untuk menguji apakah model yang digunakan dalam penelitian ini tepat atau tidak untuk dipergunakan sebagai alat analisis dalam menguji pengaruh variabel independen pada variabel dependennya. Hasil Uji F dapat dilihat pada Tabel 4.

Tabel 4.

Hasil Uji F

\begin{tabular}{lcrrrrrr}
\hline Model & $\mathbf{R}$ & $\begin{array}{c}\text { R } \\
\text { Square }\end{array}$ & $\begin{array}{c}\text { Adjusted } \\
\text { R Square }\end{array}$ & $\begin{array}{c}\text { Std. Error } \\
\text { of the } \\
\text { Estimate }\end{array}$ & $\begin{array}{c}\text { R Square } \\
\text { Change }\end{array}$ & F Change & $\begin{array}{c}\text { Sig. F } \\
\text { Change }\end{array}$ \\
\hline 1 & $.851^{\mathrm{a}}$ & .724 & .716 & .791670 & .724 & 88.436 & .000 \\
\hline Sumber: Data diolah, 2018 & & & & & &
\end{tabular}

Berdasarkan Tabel 4 dapat dilihat bahwa nilai $\mathrm{F}$ hitung sebesar 88,436 dengan signifikansi sebesar 0,00. Nilai signifikansi Uji F yang lebih kecil dari $\alpha=$ 0,05 hal ini menunjukkan bahwa model regresi sudah fit sehingga bisa diterima dan tepat untuk dipergunakan memprediksi pengaruh variabel independen (kecukupan modal, likuiditas, non performing loan) pada variabel dependen (profitabilitas). 
E-Jurnal Manajemen, Vol. 8, No. 6, 2019 :3360-3387

Uji statistik t pada dasarnya menunjukkan seberapa jauh pengaruh satu variabel independen secara individual dalam menerangkan variabel dependen. Pengujian dilakukan dengan menggunakan significance level 0,05 $(\alpha=5 \%)$. dan dapat dijelaskan sebagai berikut: 
Tabel 5.

Hasil Uji T

\begin{tabular}{lcrll}
\hline & Model & Beta & Sig. & \multicolumn{1}{c}{ Keterangan } \\
\hline CAR & & .897 & .000 & Diterima \\
LDR & & .322 & .000 & Diterima \\
NPL & & .267 & .000 & Diterima \\
\hline
\end{tabular}

Sumber: Data diolah, 2018

Berdasarkan Tabel 5 diperoleh nilai signifikansi uji $\mathrm{t}$ dari variabel Kecukupan Modal sebesar 0,000 lebih kecil dari $\alpha=0,05$ serta nilai koefisien beta sebesar 0,897. Hal ini mengidentifikasikan bahwa Kecukupan Modal berpengaruh positif dan signifikan terhadap Profitabilitas, sehingga dalam penelitian ini hipotesis pertama diterima.

Berdasarkan Tabel 5 diperoleh nilai signifikansi uji t dari variabel Likuiditas sebesar 0,000 lebih besar dari $\alpha=0,05$ serta nilai koefisien beta sebesar 0,322 . Hal ini mengidentifikasikan bahwa Likuiditas berpengaruh positif dan signifikan terhadap Profitabilitas, sehingga dalam penelitian ini hipotesis kedua diterima.

Berdasarkan Tabel 5 diperoleh nilai signifikansi uji t dari variabel Non Performing Loan sebesar 0,000 lebih kecil dari $\alpha=0,05$ serta nilai koefisien beta sebesar -0,267. Hal ini mengidentifikasikan bahwa Non Performing Loan berpengaruh negatif dan signifikan terhadap Profitabilitas, sehingga dalam penelitian ini hipotesis ketiga diterima.

Berdasarkan Tabel 4 menunjukkan bahwa besarnya koefisien determinasi adalah sebesar 0,724 . Hal ini berarti sebesar 72,4 persen variasi profitabilitas dapat dijelaskan oleh variabel bebas yaitu kecukupan modal (CAR), likuiditas (LDR), dan non performing loan, sedangkan sisanya 27,6 persen dipengaruhi oleh variabel lain diluar dari penelitian ini. 
Hipotesis dalam penelitian ini adalah kecukupan modal berpengaruh positif dan signifikan terhadap profitabilitas. Berdasarkan hasil pengujian pengaruh kecukupan modal $\left(\mathrm{X}_{1}\right)$ pada Profitabilitas $(\mathrm{Y})$ yang ditujukan pada Tabel 4.9 diketahui bahwa tingkat signifikansi uji t sebesar 0,000 yang menunjukkan angka lebih kecil daripada taraf nyata dalam penelitian ini yaitu $\alpha=0,05$ dengan nilai koefisien beta sebesar 0,897. Jadi hal ini menunjukkan bahwa kecukupan modal berpengaruh positif dan signifikan terhadap profitabilitas (ROA) pada LPD di Kota Denpasar, artinya Kecukupan Modal berpengaruh terhadap kenaikan atau peningkatan profitabilitas.

LPD dengan tingkat kecukupan modal yang tinggi akan lebih baik dalam mengelola risiko operasionalnya yang dihadapi di dalam proses pengembangan usahanya dibandingkan dengan LPD yang memiliki tingkat kecukupan modal yang rendah. Kecukupan modal diukur menggunakan rasio CAR (Capital Adequacy Ratio), CAR merupakan tolak ukur kemampuan LPD untuk menutupi penurunan aktivanya. Apabila semakin tinggi CAR maka semakin besar modal yang dimiliki oleh LPD. Jika semakin tinggi nilai CAR maka suatu LPD tersebut mampu dalam membiayai operasional dan dalam keadaan tersebut dapat memberikan kontribusi terhadap profitabilitas dan dapat meningkatkan profitabilitas tersebut.

Hasil penelitian ini menunjukkan bahwa Kecukupan Modal berpengaruh positif dan signifikan terhadap profitabilitas Hasil ini menerima hipotesis $\mathrm{H}_{1}$ yaitu kecukupan modal berpengaruh positif dan signifikan terhadap profitabilitas. Hasil penelitian ini mendukung penelitian yang dilakukan oleh Hendriartha (2014), 
I Gst Ayu Nyoman Krisnia Putri, Pengaruh Kecukupan Modal......

Suardita (2015), Hartono (2017), Abdilah et al. (2016), Putri (2017), Purnamawati (2014) yang menyatakan bahwa kecukupan modal berpengaruh positif dan signifikan terhadap profitabilitas.

Hipotesis dalam penelitian ini adalah Likuiditas berpengaruh positif dan signifikan terhadap profitabilitas. Berdasarkan hasil pengujian pengaruh Likuiditas $\left(\mathrm{X}_{2}\right)$ pada Profitabilitas $(\mathrm{Y})$ yang ditujukan pada Tabel 5 diketahui bahwa tingkat signifikan uji t sebesar 0,000 yang menunjukkan angka lebih kecil daripada taraf nyata dalam penelitian ini yaitu $\alpha=0,05$ dengan nilai koefisien beta sebesar 0,322. Jadi hal ini menunjukkan bahwa Likuiditas berpengaruh positif dan signifikan terhadap profitabilitas (ROA) pada LPD di Kota Denpasar, artinya Likuiditas berpengaruh terhadap kenaikan atau peningkatan profitabilitas.

Likuiditas merupakan kemampuan perusahaan untuk memenuhi kewajiban finansialnya dalam jangka pendek dengan dana lancar yang tersedia (Wiagustini, 2010:76). Likuiditas diukur menggunakan rasio LDR, jika LDR meningkat berarti kredit yang disalurkan kepada masyarakat meningkat dan dapat meningkatkan profitabilitas, namun penyaluran kredit yang berjumlah besar akan berpotensi pada kredit macet dan dapat menurunkan profitabilitas, jika kredit yang disalurkan secara efektif maka akan dapat meningkatkan keuntungan.

Hasil penelitian ini menunjukkan bahwa Likuiditas berpengaruh positif dan signifikan terhadap profitabilitas.Hasil penelitian ini menerima hipotesis $\mathrm{H}_{2}$ yaitu Likuiditas berpengaruh positif dan signifikan terhadap profitabilitas. Hasil penelitian ini mendukung penelitian yang dilakukan olehMakkar dan Hardeep (2018), Putri (2017), Ariani (2017), Brewer (2014), Abdilah et al. (2016), 
Anshika (2016), Takon dan Atseye (2015)yang menyatakan bahwa Likuiditas berpengaruh positif dan signifikan terhadap profitabilitas.

Hipotesis dalam penelitian ini adalah Non PerformingLoan berpengaruh negatif dan signifikan terhadap Profitabilitas. Berdasarkan hasil pengujian pengaruh Non PerformingLoan $\left(\mathrm{X}_{3}\right)$ pada Profitabilitas $(\mathrm{Y})$ yang ditujukan pada Tabel 5 diketahui bahwa tingkat signifikansi uji $\mathrm{t}$ sebesar 0,000 yang menunjukkan angka lebih kecil daripada taraf nyata dalam penelitian ini yaitu $\alpha=$ 0,05 dengan nilai koefisien beta sebesar -0,267. Jadi hal ini menunjukkan bahwa Non Performing Loan berpengaruh negatif dan signifikan terhadap profitabilitas (ROA) pada LPD di Kota Denpasar, artinya apabila terjadi peningkatan pada Non PerformingLoan maka Profitabilitas mengalami penurunan.

Non Performing Loan adalah pinjaman yang mengalami kesulitas pelunasan atau sering disebut sebagai kredit macet pada bank. NPL berpengaruh terhadap penyaluran kredit perbankan dimana terdapat kredit yang memiliki kualitas kredit buruk yang sering disebut dengan kredit bermasalah (Putri, 2017). semakin tinggi kredit bermasalah dalam pengelolaan kredit bank maka akan menurunkan tingkat profitabilitas, jadi LPD tersebut tidak professional dalam pengelolaan kreditnya, jika semakin rendah tingkat Non PerformingLoan maka semakin tinggi tingkat Profitabilitas LPD tersebut.

Hasil penelitian ini menunjukkan bahwa Non PerformingLoan berpengaruh negatif dan signifikan terhadap profitabilitas. Hasil ini menerima hipotesis $\mathrm{H}_{3}$ yaitu Non PerformingLoan berpengaruh negatif dan signifikan terhadap profitabilitas. Hasil penelitian ini mendukung penelitian yang dilakukan oleh 
I Gst Ayu Nyoman Krisnia Putri, Pengaruh Kecukupan Modal......

Hartono (2017), Puspitasari et al. (2015), Kristianti dan Yovin (2016), Putri (2015), Putri (2017), Ariani (2015) yang menyatakan bahwa Non PerformingLoan berpengaruh negatif dan signifikan terhadap profitabilitas.

\section{SIMPULAN DAN SARAN}

Kecukupan Modal berpengaruh positif dan signifikan terhadap Profitabilitas pada LPD di Kota Denpasar periode 2015 - 2017. Hal ini berarti kecukupan modal berpengaruh terhadap kenaikan profitabilitas, tingkat kecukupan modal yang tinggi akan lebih baik dalam mengelola risko operasionalnya dalam keadaan tersebut dapat memberikan kontribusi terhadap profitabilitas, jika semakin tinggi kecukupan modal maka akan mampu meningkatkan profitabilitas pada Lembaga Perkreditan Desa di Kota Denpasar.

Likuiditas berpengaruh positif dan signifikan terhadap Profitabilitas pada LPD di Kota Denpasar periode 2015 - 2017. Hal ini berarti likuiditas berpengaruh terhadap kenaikan profitabilitas, jika LDR meningkat maka jumlah dana yang disalurkan dalam bentuk kredit juga akan meningkat dan semakin tinggi jumlah pendapatan yang diterima dan dapat meningkatkan profitabilitas pada Lembaga Perkreditan Desa di Kota Denpasar.

Non Performing Loan berpengaruh negatif dan signifikan terhadap Profitabilitas pada LPD di Kota Denpasar periode 2015 - 2017. Hal ini berarti jika terjadi peningkatan pada Non Performing Loan maka profitabilitas mengalami penurunan, jika semakin tinggi kredit bermasalah dalam pengelolaan kreditnya maka akan menurunkan tingkat profitabilitas pada Lembaga Perkreditan Desa di Kota Denpasar. 
Lembaga Perkreditan Desa di Kota Denpasar disarankan memperhatikan risiko Kecukupan Modal (CAR), Likuiditas (LDR), dan Non Performing Loan (NPL). Lembaga Perkreditan Desa diharapkan memperhatikan jumlah modal yang ada karena modal tersebut mencerminkan bagaimana kemampuan LPD dalam menghadapi risiko kerugian yang mungkin timbul dan menjaga tingkat kecukupan modalnya yang telah ditetapkan oleh peraturan gubernur bali yaitu sebesar minimum 12\%. Selain itu dari faktor Likuiditas Lembaga Perkreditan Desa diharapkan lebih memaksimalkan lagi dalam penyaluran kreditnya secara efektif agar dapat meningkatkan profitabilitas selain itu harus menjaga stabilitas likuiditasnya yang telah ditetapkan oleh peraturan bank Indonesia yaitu 78\% 92\%. Dari faktor Non Performing Loan Lembaga Perkreditan Desa diharapkan memiliki tingkat risiko kredit yang rendah dan dalam pengelolaan kreditnya yang efektif dapat menerapkan prinsip kehati-hatian dan harus memperkuat analisa kreditnya sebelum pemberian kredit dilakukan.

Variabel yang digunakan dalam penelitian ini hanya terbatas pada variabel Kecukupan Modal (CAR), Likuiditas (LDR), Non Performing Loan, dan Profitabilitas (ROA). Diharapkan bagi peneliti selanjutnya dapat menambahkan variabel-variabel lain yang dapat berpengaruh terhadap Profitabilitas seperti Perputaran Modal, Perputaran Kas, Risiko Operasional (BOPO), Net Interest Margin (NIM), dan Dana Pihak Ketiga (DPK), serta menambah periode waktu peneliti, sebagai tambahan referensi terhadap variabel yang diteliti agar dapat memperluas penelitian dan menghasilkan analisis yang lebih baik. 


\section{REFERENSI}

Abdilah Rahmat, Hosen Muhamad Nadratuzzaman, Muhari Syafaat. (2016). The Determinants Factor Of Islamic Bank's Profitability And Liquidity In Indonesia. Knowledge Horizons - Economics. 8(2), Pp. 140-147

Acaravci, Songul Kakilli\&Calim, Ahmet Ertugrul. (2013). Turkish Banking Sector's Profitability Factors.International Journal of Economics and Financial Issues. 3(1), Pp.27-41

Alshatti, Ali Sulieman.(2015).The Effect of the Liquidity Management on Profitability in the Jordanian Commercial Banks. International Journal of Business and Management. 10(1), Pp. 62-71

Anshika. (2016). Impact of Financial Risk Management on Capital Adequacy and Profitability -A Panel Study of Selected Indian Commercial Banks.Splint International Journal of Professionals. 3(3) Pp. 136-147

Ariani, Made Windi, Ardiana, Putu Agus. (2015). Pengaruh Kecukupan Modal, Tingkat Efisiensi, Risiko Kredit, Dan Likuiditas Pada Profitabilitas LPD Kabupaten Badung. E-Jurnal Akuntansi Universitas Udayana. hal. 259275.

Arif Ahmed, Anees Ahmed Nauman. (2012). Liquidity risk and performance of banking system in Pakistan. Journal of Financial Regulation and Compliance. 20(2), Pp. 182-195

Asri, Ni Nyoman Sri. (2018). Pengaruh Dana Pihak Ketiga, Capital Adequacy Ratio, Likuiditas, dan Ukuran Perusahaan Terhadap Profitabilitas Pada LPD Kabupaten Gianyar. E-Jurnal Manajemen Unud. 7(6), Pp. 33843411 .

Avrita, Riska Diba dan Pangestu, Irene Rini Demi. (2016). Analisis Pengaruh CAR, NPL, LDR, NIM, dan BOPO Terhadap Profitabilitas Bank. Diponegoro Journal Of Management. 5 (2), hal. 2337-3792.

Brewer, Guy R. (2014). Factors affecting U.S. Banking Performance: Evidence From the 2007-(2013) Financial Crisis.International Journal of Economics, Finance and Management.3(6), Pp. 282-295.

Chou, Te-Kuang, Buchdadi Agung Dharmawan. (2016). Bank Performance and Its Underlying Factors: A Study of Rural Banks in Indonesia. Accounting and Finance Research. 5(3), Pp. 55-63 
Feranika, Fia. (2016). Pengaruh Rasio Kecukupan Modal, Non Performing Loan, Likuiditas Dan Dana Pihak Ketiga Terhadap Profitabilitas Perbankan Go Publik Di BEI. hal. 3-12

Hanafi, Mahmuh dan Abdul Halim. (2012). Analisis Laporan Keuangan. Edisi Ketiga. Yogyakarta: Sekolah Tinggi Ilmu Manajemen YKPN

Hantono. (2017). Effect Of Capital Adequacy Ratio (CAR), Loan To Deposit Ratio (LDR) And Non Performing Loan (NPL) To Return On Assets (ROA) Listed In Banking In Indonesia Stock Exchange . International Journal of Education and Research. 5(1), Pp. 69-80

Hendiartha, I Gusti Ngurah Edi. (2015). Pengaruh Kecukupan Modal, Likuiditas, Net Interest Margin dan Perputaran Kas Terhadap Profitabilitas Pada LPD Di Kecamatan Abiansemal. E-Jurnal Manajemen Unud. 4(12), hal. 41354159.

Ismail. (2014). Akuntansi Bank : Teori dan Aplikasi dalam Rupiah Edisi Revisi. Jakarta: Kencana Prenadamedia Group

Ismaulina dan Zulfadhli. (2016). Effect Of Capital Adequacy, Liquidity And Operational Efficiency To Profitability In Bank Syariah Mandiri (Period 2008 s.d. (2015)). Jurnal Ilmiah Syari ‘ah. 15(1), Pp. 43-54

Kasmir. (2004). Manajemen Perbankan. Edisi Pertama, Cet.5. Jakarta: PT. Raja Grafindo Persada. .(2010). Analisis Laporan Keuangan. Jakarta: PT. Raja Grafindo Persada. . (2012). Analisis Laporan Keuangan. Jakarta: Rajawali Pers. .(2013).Bank Dan Lembaga Keuangan Lainnya. Jakarta: PT Raja Grafindo Persada

. (2014). Bank dan Lembaga Keuangan lainnya. Edisi Revisi. Jakarta: PT. Raja Grafindo Persada

Kristianti, Rina Adi, Yovin. (2016). Factors Affecting Bank Performance: Cases of Top 10 Biggest Government and Private Banks in Indonesia in 2004 (2013). Review of Integrative Business and Economics Research. 5(4), Pp. 371-378

Mahmoedin, AS. (2001). Melacak Kredit Bermasalah. Jakarta: Pustaka Sinar Harapan. 
Makkar, Anita, Hardeep. (2018). Key factors influencing profitability of Indian commercial banks.International Journal of Academic Research and Development . Vol.3. Pp 373-378

Pinasti, Wildan Farhat, Mustikawati, R.R Indah. (2018). Pengaruh CAR, BOPO, NPL, NIM DAN LDR Terhadap Profitabilitas Bank Umum Periode (2011)-(2015). Jurnal Nominal. 3(1), hal. 126-142.

Pradhan, Radhe Shyam, Parajuli Pratikshya. (2017). Impact of Capital Adequacy and Cost Income Ratio on Performance of Nepalese Commercial Banks. International Journal of Management Research. 8(1), Pp. 6-18

Prasanjaya A.A. Yogi, Ramantha I Wayan. (2013). “Analisis Pengaruh Rasio CAR, BOPO, LDR dan Ukuran Perusahaan terhadap Profitabilitas Bank yang Terdaftar Di BEI, E-Jurnal Akuntansi Universitas Udayana. 4(1), hal. 2302-8556.

Primadewi, Cok Istri Dian Rini, dan Suputra , I Dewa Gede Dharma. (2015). PengaruhCapital Adequacy Ratio, Non Performing Loan dan Dana Pihak Ketiga Pada Profitabilitas. E-Jurnal Akuntansi Universitas Udayana.12(3), hal. 2302-8556.

Purnamawati, I Gusti Ayu. (2014). The Effect Of Capital And Liquidity Risk To Profitability On Conventional Rural Bank In Indonesia. South East Asia Journal of Contemporary Business, Economics and Law. 5(1), Pp. 44-50.

Puspitasari, M. Devy, Setyadi Nugroho J, Rizkiyanti Nurrina. (2015). Implementation Of The Indonesia Banking Architecture As A Blueprint Of The Direction And Order Of The National Banking System: Emprical Study Of Indonesian Commercial Banking. Journal The WINNERS. 16(1), Pp. 6-14

Putri, Chandra Chintya. (2015). Pengaruh NPL, LDR, CAR Terhadap Profitabilitas Bank Umum Swasta Nasional Devisa. Jurnal Ilmu Dan Riset Manajemen. 4(4)

Putri, Fifit Syaiful. (2013). Pengaruh Risiko Kredit Dan Tingkat Kecukupan Modal Terhadap Tingkat Profitabilitas Pada Perusahaan Perbankan Yang Terdaftar Di Bursa Efek Indonesia. E-journal unp. Hal. 3-25

Putri, Rosana Nur Oktavia Subagiono. (2017). Pengaruh LDR, CAR, NPL, BOPO Terhadap Profitabilitas Lembaga Perkreditan Desa Di Kota Denpasar. EJurnal Manajemen Unud. 6(10), hal. 5607-5635.

Riyadi, Slamet. 2006. Banking Asset and Liability Management, edisi ketiga. Jakarta: Fakultas Ekonomi Universitas Indonesia 
Sartono, R. Agus. (2001). Manajemen Keuangan Teori dan Aplikasi. Edisi Keempat. Yogyakarta:BPFE

_ _ R. Agus. (2014). Manajemen Keuangan Teori dan Aplikasi. Yogyakarta: BPFE-yogyakarta.

Siamat, Dahlan. (2001). Manajemen Lembaga Keuangan. Edisi Ketiga. Jakarta: Lembaga Penerbit Fakultas Ekonomi Universitas Indonesia

Suardita, I Wayan, dan Putri. I G A M Asri Dwija. (2015). Pengaruh Kecukupan Modal Dan Penyaluran Kredit Pada Profitabilitas Dengan Pemoderasi Risiko Kredit. E-Jurnal Akuntansi Universitas Udayana. 11(2), hal. 23028556.

Takon, Samuel Manyo, AtseyeFidelis Anake. (2015). Effect Of Working Capital Management On Firm Profitability In Selected Nigerian Quoted Companies.International Journal of Economics, Commerce and Management. 3(10), Pp. 414-438.

Wiagustini. Ni Luh Putu. (2010). Dasar-dasar Manajemen Keuangan. Denpasar. Udayana University Press 